Brit. J. vener. Dis. (1956), 32, 117.

\title{
TREATMENT OF GONORRHOEA WITH SPIRAMYCIN * $†$
}

\author{
BY \\ R. R. WILLCOX \\ St. Mary's Hospital, London, W.2
}

Spiramycin is a relatively new antibiotic prepared from Streptomyces ambofaciens which was first isolated from a soil sample by French workers. It was reported on by Pinnert-Sindico, Ninet, PreudHomme and Cosar at the Washington Symposium on Antibiotics in 1954. It is available as a sulphate in yellowish capsules each of $0.5 \mathrm{~g}$. protected by a thin coat of varnish.

So far there have been few reports of its use in the clinical field. Earlier this year Hudson, Yoshihara, and Kirby (1956) recorded 29 cases of pneumonia treated with the drug, and noted that, although Gram-positive cocci were inhibited by low concentrations, they were less sensitive to Spiramycin than to penicillin or erythromycin. More important, perhaps, was the observation that most strains of staphylococci which were resistant to penicillin and streptomycin were sensitive to Spiramycin.

\section{Material}

This report concerns 85 male cases of previously untreated, uncomplicated gonorrhoea treated orally with Spiramycin. Their average age was 27.9 years (extremes 15 and 49): 67 were white, seventeen were Negroes (fourteen from the West Indies and three from West Africa), and one was an Indian. Twenty-one patients were married and 64 were single. Thirty-eight patients (seven Negroes) admitted no previous venereal incident. The remaining 47 had between them had no less than 66 attacks of gonorrhoea, 21 of non-gonococcal urethritis, one of syphilis, one of pediculosis pubis, and one of venereal warts. The average number of previous venereal incidents for the eighteen non-white persons (twenty attacks of gonorrhoea and two of non-gonococcal urethritis) was 1.2 as compared with 1.0 for the whiteskinned persons.

The urethral discharge had been present for 1 to 3 days before treatment in 65 , from 4 to 7 days in fifteen, and for more than 7 days in five. Sixty-one patients

* Received for publication March 14, 1956.

+ This material was presented to the M.S.S.V.D., London, on February 24, 1956, and at the International Symposium on Venereal Diseases and Treponematoses, Washington, D.C., May, 1956. owned to experiencing dysuria and 24 did not. The infection was acquired from a stranger in 55 (five being known prostitutes), from a friend or acquaintance in 22, from a marital source in one, from homosexual exposure in three, and exposure was denied in four cases. The apparent incubation period was from 1 to 3 days in forty, from 4 to 7 days in 27 , from 8 to 14 days in ten, over 14 days in four, and unknown in four.

The Wassermann and VDRL reactions were both negative in eighty. Four persons had a negative Wassermann and a doubtful VDRL reaction and one showed a doubtful Wassermann and a negative VDRL reaction. The gonococcal complement-fixation test was done in 72 cases. The result was negative in 62 , positive in four, doubtful in five, and anticomplementary in one.

\section{Dosage}

Multiple.-In 31 cases multiple dosage was used. This consisted of $12 \mathrm{~g}$. over 2 days in six ; $9 \mathrm{~g}$. over 2 days in six ; 6 g. over 2 days in six; 8 g. over 1 day in one; $6 \mathrm{~g}$. over 1 day in six; and 4 to $4.5 \mathrm{~g}$. over 1 day in six. Three or four doses of the drug were given each day. At the beginning of the study the higher dosages were used but, as the results were uniformly good, the dose was gradually reduced. There was only one gonococcus-positive failure amongst the 26 cases followed ( 3.9 per cent.) occurring at 2 to 3 months from treatment, and there was good reason to believe this to be a reinfection. There were also two cases of nongonococcal infection noted during the first 3 months of observation (Table I, overleaf).

Single.-Having established that Spiramycin was effective in gonorrhoea, the possibility of using a single dose treatment was next explored, 54 patients being treated. Ten were given single doses of $4 \mathrm{~g}$.; twenty had single doses of 3 g., and 24 were given only $2 \mathrm{~g}$. The follow-up and results are shown in Table II (overleaf).

There were thus ten relapses or re-infections in the 47 cases followed. The differentiation of 
TABLE I

RESULTS OF TREATMENT OF 31 CASES OF ACUTE GONORRHOEA WITH 4-12 g. SPIRAMYCIN IN DIVIDED DOSES OVER 1-2 DAYS

\begin{tabular}{|c|c|c|c|c|}
\hline \multicolumn{2}{|l|}{$\begin{array}{l}\text { Duration of } \\
\text { Follow-up }\end{array}$} & $\begin{array}{c}\text { Cases } \\
\text { Followed }\end{array}$ & $\begin{array}{l}\text { Gonococcus- } \\
\text { positive } \\
\text { Failure }\end{array}$ & $\begin{array}{c}\text { Non- } \\
\text { gonococcal } \\
\text { Urethritis }\end{array}$ \\
\hline $\begin{array}{l}0 \\
1-3 \text { days } \\
4-7 \text { days } \\
8-14 \text { days } \\
15-21 \text { days } \\
22-28 \text { days } \\
1-2 \text { months } \\
2-3 \text { months } \\
\text { Over } 3 \text { months }\end{array}$ & $\begin{array}{l}\ldots \\
\cdots \\
\cdots \\
\cdots \\
\cdots \\
\cdots\end{array}$ & $\begin{array}{r}31 \\
26 \\
22 \\
20 \\
17 \\
17 \\
17 \\
11 \\
4\end{array}$ & $\begin{array}{l}\bar{z} \\
\bar{z} \\
\overline{1}^{*}\end{array}$ & $\begin{array}{l}- \\
\frac{1}{1} \\
\overline{1} \\
1\end{array}$ \\
\hline Total & . & 26 & 1 & 3 \\
\hline
\end{tabular}

TABLE III

SINGLE DOSE SCHEDULES

\begin{tabular}{c|c|c|c|c|c|c}
\hline $\begin{array}{c}\text { Dose } \\
\text { (g.) }\end{array}$ & $\begin{array}{c}\text { Cases } \\
\text { Treated }\end{array}$ & $\begin{array}{c}\text { Cases } \\
\text { Fol- } \\
\text { lowed }\end{array}$ & Rolapse & Re-infection & $\begin{array}{c}\text { Non- } \\
\text { Gono- } \\
\text { coccal } \\
\text { Ureth- } \\
\text { ritis }\end{array}$ & $\begin{array}{c}\text { GC }+ \\
(\%) \\
\text { Fol- } \\
\text { lowed }\end{array}$ \\
\hline 4 & 10 & 9 & - & 1 & 1 & $11 \cdot 1$ \\
3 & 20 & 16 & - & 3 & 1 & $18 \cdot 8$ \\
2 & 24 & 22 & 6 & - & 1 & $27 \cdot 3$ \\
\hline Total & 54 & 47 & 6 & 4 & 3 & $21 \cdot 3$ \\
\hline
\end{tabular}

relapse from re-infection is no less a problem in the evaluation of the results of treatment of gonorrhoea than of syphilis. Three of the four suspected reinfections occurred during or after the 22 to 28 days period of observation, whereas all of the six relapses were noted within 14 days. There were also three cases of non-gonococcal infection. These failures are related to dosage in Table III.

All of the four failures amongst the 25 cases followed who had received single doses of 3 or $4 \mathrm{~g}$. were considered to be re-infections, and all of the six failures in the 22 followed who had received only $2 \mathrm{~g}$. were considered to be relapses.

Side-Effects. - No significant side-effects to Spiramycin were noted in the 85 persons treated.

\section{Summary and Conclusions}

(1) 85 cases of acute uncomplicated gonorrhoea were treated with Spiramycin.
TABLE II

RESULTS OF TREATMENT OF 54 CASES OF GONORRHOEA WITH SINGLE DOSES OF $2-4 \mathrm{~g}$. OF SPIRAMYCIN

\begin{tabular}{|c|c|c|c|c|c|}
\hline \multirow{2}{*}{\multicolumn{2}{|c|}{$\begin{array}{l}\text { Duration of } \\
\text { Follow-up }\end{array}$}} & \multirow[b]{2}{*}{$\begin{array}{c}\text { Cases } \\
\text { Followed }\end{array}$} & \multicolumn{2}{|c|}{ Gonococcus-positive } & \multirow{2}{*}{$\begin{array}{c}\text { Non- } \\
\text { gonococcal } \\
\text { Urethritis }\end{array}$} \\
\hline & & & $\begin{array}{c}\text { Suspected } \\
\text { Relapse }\end{array}$ & $\begin{array}{l}\text { Suspected } \\
\text { Re-infec- } \\
\text { tion }\end{array}$ & \\
\hline $\begin{array}{l}0 . . \\
1-3 \text { days } . . \\
4-7 \text { days } . . \\
8-14 \text { days } \\
15-21 \text { days } \\
22-28 \text { days } \\
1-2 \text { months } \\
2-3 \text { months } \\
\text { Over } 3 \text { months }\end{array}$ & $\begin{array}{l}. . \\
\ldots \\
\ldots \\
\ldots \\
\ldots \\
\ldots\end{array}$ & $\begin{array}{r}54 \\
47 \\
44 \\
34 \\
23 \\
22 \\
17 \\
6 \\
6 \\
3\end{array}$ & $\begin{array}{l}\bar{Z} \\
4 \\
2 \\
= \\
= \\
=\end{array}$ & $\begin{array}{l}\frac{-}{1} \\
\frac{1}{1} \\
1 \\
\frac{1}{-}\end{array}$ & $\begin{array}{l}= \\
\frac{1}{1} \\
\frac{1}{-}\end{array}$ \\
\hline Total & . & 47 & 6 & 4 & 3 \\
\hline Per cent. & . & 100 & $12 \cdot 8$ & $8 \cdot 5$ & $6 \cdot 4$ \\
\hline
\end{tabular}

(2) Of 31 patients given 4 to $12 \mathrm{~g}$. in multiple doses over 1 to 2 days there was only one gonococcus-positive failure which was considered to be a re-infection.

(3) Of thirty patients given single doses of 3 or $4 \mathrm{~g}$., there were four possible failures, all of which were believed to be re-infections.

(4) Of 24 patients given single doses of 2 g., there were six gonococcus-positive failures all of which were considered to be relapses.

(5) Non-gonococcal urethritis was observed within 3 months after the treatment of gonorrhoea in five of the 73 patients followed (6.8 per cent.).

(6) No significant side-effects were noted in the entire series.

(7) It is concluded that Spiramycin in multiple doses totalling 4 to $12 \mathrm{~g}$. given orally over 1 to 2 days gives excellent results in the treatment of gonorrhoea. It will also cure the disease in single doses of 3 to $4 \mathrm{~g}$., although the evidence presented is a little less firm. The percentage of cures obtained with single doses of $2 \mathrm{~g}$. is unsatisfactory.

Grateful acknowledgments are expressed to Messrs. May and Baker, Ltd., of Dagenham, Essex, for kindly providing the Spiramycin used in this study.

\section{REFERENCES}

Hudson, D. G., Yoshihara, G. H., and Kirby, W. M. M. (1956). Arch. intern. Med., 97, 57.

Pinnert-Sindico, S. (1954). Ann. Inst. Pasteur, 87, 702.

-. Ninet, L., Preud-Homme, J., and Cosar, C. (1954). Symposium on Antibiotics, Washington, October 25-29. 